By

D. D. Brown

A. S. Nagel

July, 1999

Work Performed Under Contract No. DE-AC24-81NE44139

Prepared by

West Valley Nuclear Services Co.

10282 Rock Springs Road

West Valley, NY 14171-9799 


\section{DISCLAIMER}

This report was prepared as an account of work sponsored by an agency of the United States Government. Neither the United States Government nor any agency thereof, nor any of their employees, makes any warranty, express or implied, or assumes any legal liability or responsibility for the accuracy, completeness, or usefulness of any information, apparatus, product, or process disclosed, or represents that its use would not infringe privately owned rights. Reference herein to any specific commercial product, process, or service by trade name, trademark, manufacturer, or otherwise, does not necessarily constitute or imply its endorsement, recommendation, or favoring by the United States Government or any agency thereof. The views and opinions of authors expressed herein do not necessarily state or reflect those of the United States Government or any agency thereof.

This report has been reproduced directly from the best available copy.

Available to DOE and DOE contractors from the Office of Scientific and Technical information, PO Box 62, Oak Ridge, TN 37831; prices available from (615) 576-8401, FTS 626-8401.

Available to the public from the National Technical Information Service, U. S. Department of Commerce, 5285 Port Royal Road, Springfield, VA 22161. 
DOE/NE/44139-90

Distribution Category UC-510

\title{
STRONTIUM-90 ERROR DISCOVERED \\ IN SUBCONTRACT LABORATORY
}

\author{
Topical Report
}

By

D. D. Brown

A. S. Nagel

July, 1999

Work Performed Under Contract No. DE-AC24-81NE 44139

Prepared for

U.S. Department of Energy

Assistant Secretary for Nuclear Energy

Prepared by

West Valley Nuclear Services Co.

10282 Rock Springs Road

West Valley, NY 14171-9799 



\section{TABLE OF CONTENTS}

Section

Page

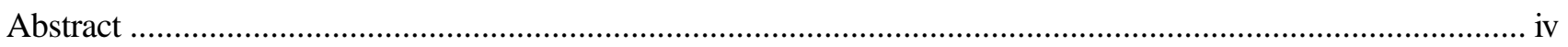

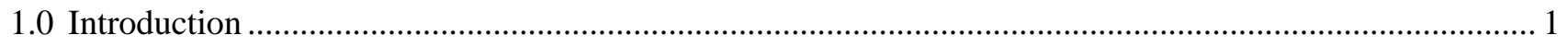

2.0 Environmental Data Assessment at the WVDP that Led to Discovery of the Errors ................................ 2

3.0 Detailed Description of Errors and Correct Equations that were Substituted ............................................. 3

3.1 The Subcontractor Laboratory's Derivation of 90Sr Concentration and WVNS' Correction ................. 3

3.2 Derivation of Uncertainty Term ............................................................................................ 6

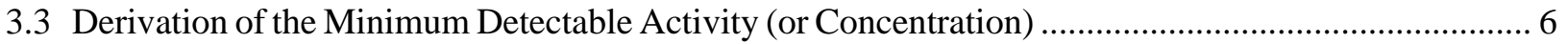

4.0 Communication Between The subcontractor laboratory and WVNS Regarding Corrective Actions ............. 7

4.1 Communications with Subcontractor Laboratory Leading up to Quality Assurance (QA) Surveillance . 7

4.2 Communication During WVNS QA Surveillance of Subcontractor Laboratory .................................. 8

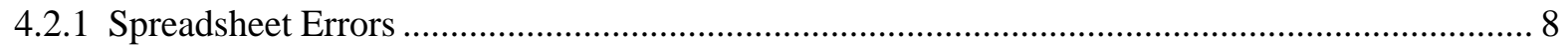

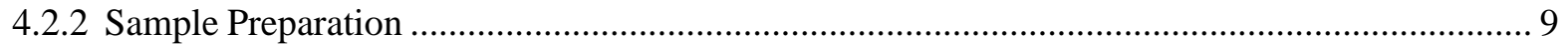

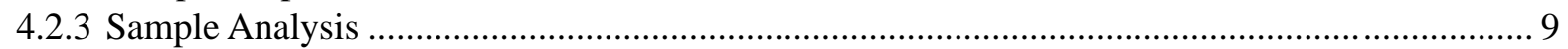

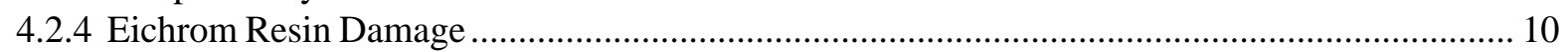

4.2.5 Software Verification and Validation Procedures ................................................................... 11

4.2.6 Summary of Subcontractor Laboratory Actions Agreed to During Surveillance ....................... 11

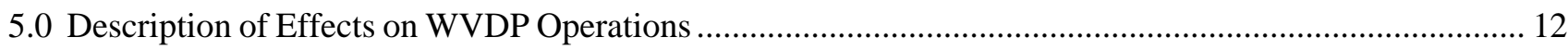

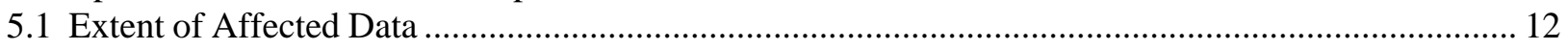

5.2 Effort Required to Restore WVDP Environmental Database ....................................................... 12

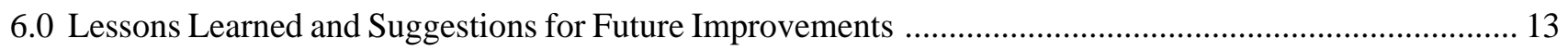

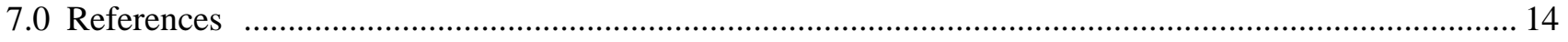


In January 1998, health physicists and environmental scientists at the West Valley Demonstration Project (WVDP) discovered a series of errors in a spreadsheet used by a subcontracted laboratory to reduce data as part of their strontium-90 ( $\left.{ }^{90} \mathrm{Sr}\right)$ analytical procedure. This report was prepared to summarize the data assessment process that led to this discovery, to describe the process of identifying and correcting the errors, and to describe the effects of these errors on our operations. Lessons learned and a brief summary of how the WVDP intends to avoid this kind of problem in the future are also presented. 


\subsection{INTRODUCTION}

As the West Valley Demonstration Project (WVDP) approaches its ultimate goals of high-level waste vitrification, final decontamination, and site closure, its environmental monitoring program continues to demonstrate that public health and safety and the environment are being protected with respect to releases of radioactive and hazardous substances from site operations and from the waste materials stored on site. The environmental monitoring program, as implemented by West Valley Nuclear Services Company (WVNS), is also intended to demonstrate compliance with federal and state requirements.

The full implementation of the WVDP environmental monitoring program requires the services of off-site subcontract laboratories that can provide a majority of the analyses requiring radiochemical separation, as well as analyses for chemical parameters not measured by the WVDP on-site Environmental Laboratory. The subcontractor laboratory, a radiochemical services provider, has contracted with the WVDP to provide radiological analysis services for environmental and waste management programs since February 1995.

In January 1998, health physicists and environmental scientists in the WVNS Environmental Affairs Department discovered a series of errors in a spreadsheet used by the subcontractor laboratory to reduce data as part of their strontium-90 ( $\left.{ }^{90} \mathrm{Sr}\right)$ analytical procedure. This report summarizes the data assessment process that led to this discovery, describes the process of identifying and correcting the errors, and describes the effects of these errors on WVDP operations. Lessons learned and a brief summary of how the WVDP intends to avoid this kind of problem in the future are also presented. 


\subsection{EMVIRONMENTAL DATA ASSESSMENT AT THE WWDP THAT LEDTODISCOVERY OF THE ERRORS}

Environmental monitoring program data assessment for the WVDP is performed at least monthly at the direction of WVNS Environmental Affairs by the Environmental Affairs Support organization of Dames \& Moore (D\&M). D\&M is a subcontracted environmental services provider with an on-site staff. The data assessment process is a systematic process for reviewing and comparing a body of data against data quality objectives, regulatory limits, standards set forth in guidance documents, background levels, expected or anticipated values, and/or historical values. Detailed criteria for analyzing the data on a monthly basis are documented in procedures used by health physicists and environmental scientists in the Environmental Affairs Support organization.

In addition to the monthly data assessment process, further review of the environmental monitoring data occurs during preparation of the annual WVDP Site Environmental Report. It was during the review of the 1997 biological sample analysis data, provided by a subcontractor laboratory for samples collected near the end of calendar year 1997, that a health physicist noted some unusual ${ }^{90} \mathrm{Sr}$ results. Furthermore, the data packages received from the subcontractor laboratory for these biological samples referred to a change that the subcontractor laboratory made in the sample preparation procedure used for analysis for ${ }^{90} \mathrm{Sr}$. These observations prompted WVDP environmental scientists to request complete sample analysis documentation from the subcontractor laboratory as is provided for in the extant contract.

Upon receipt of the raw data and other supporting documentation, WVDP environmental scientists could not reproduce the calculation of the reported ${ }^{90} \mathrm{Sr}$ concentrations. Further investigation led to the discovery that the spreadsheet used by the subcontractor laboratory to calculate concentrations of ${ }^{90} \mathrm{Sr}$ in environmental media contained errors. The following is a description of the errors, the expected magnitude of the bias associated with these errors, and suggestions for the correction of these errors.

Note: The analytical method and associated calculations used by the subcontractor laboratory for the analysis of ${ }^{90} \mathrm{Sr}$ in environmental media assumes that ${ }^{89} \mathrm{Sr}$ is not present. This assumption is acceptable because the WVDP has advised the subcontractor laboratory that strontium $-89\left({ }^{89} \mathrm{Sr}\right)$ is not expected to be present. 


\section{0 DETAILEDDESCRIPTION OF ERRORS ANDCORRECT EQUATIONS THAT WERE SUBSTITUTED}

The discussion in this section is limited to the technical details of the spreadsheet errors and the correct spreadsheet cell formulas that were derived by WVNS to replace them. The errors affected the subcontractor laboratory's calculation of ${ }^{90} \mathrm{Sr}$ concentrations (3.1), analytical uncertainty terms (3.2), and minimum detectable concentrations (3.3). Ancillary effects on WVDP schedules, the time and monetary costs associated with correcting the errors, and the time involved in notifying customers are discussed in subsequent sections.

\subsection{The Subcontractor Laboratory's Derivation of ${ }^{90} \mathrm{Sr}$ Concentration and WVNS' Correction}

The following discussion pertains to information provided on a fax from the subcontractor laboratory to WVDP environmental scientists on February 17, 1998. This fax outlined the derivation of a formula that was intended for use by the subcontractor laboratory to correct for the effect of yttrium-90 $\left({ }^{90} \mathrm{Y}\right)$ ingrowth in samples prepared for ${ }^{90} \mathrm{Sr}$ assay using a gas proportional counter (GPC). Since the GPC does not discriminate between ${ }^{90} \mathrm{Sr}$ and ${ }^{90} \mathrm{Y}$ beta emissions, a calculated ${ }^{90} \mathrm{Y}$ ingrowth correction is needed.

The derivation begins with the statement that

$$
\text { Sr-90 DPM = Y-90 DPM }
$$

Subcontractor Laboratory Eq. 1

where $\mathrm{Sr}-90 \mathrm{DPM}=$ disintegrations per minute of ${ }^{90} \mathrm{Sr}$ in the sample and $\mathrm{Y}-90 \mathrm{DPM}=$ disintegrations per minute of ${ }^{90} \mathrm{Y}$ in the sample.

This equation is an approximation that is true for any material containing ${ }^{90} \mathrm{Sr}$ so long as the amount of time that has elapsed since any perturbation of the equilibrium condition is significantly greater than the half-life of ${ }^{90} \mathrm{Y}$ $\left(\mathrm{t}_{1 / 2}=64.1\right.$ hours $)$. Since the chemical separation of ${ }^{90} \mathrm{Sr}$ from the sample matrix, which is required for accurate ${ }^{90} \mathrm{Sr}$ assay, upsets the equilibrium condition and the sample must generally be assayed soon after this separation to meet customer contractual obligations, the assumption of secular equilibrium in estimating the amount of ${ }^{90} \mathrm{Sr}$ present in a sample prepared for radioassay would be incorrect. This fact was recognized by the subcontractor laboratory in their second equation:

$$
\text { Sr-90 DPM= }=\frac{\text { Y-90 DPM }}{\text { INGTH }}
$$

Subcontractor Laboratory Eq. 2

where INGTH, though not explicitly defined by the subcontractor laboratory in the February 17, 1998 fax, is the term that describes the increasing activity of the daughter, ${ }^{90} \mathrm{Y}$, as it approaches secular equilibrium with the parent, ${ }^{90} \mathrm{Sr}$. The definition of this term is commonly simplified in circumstances such as this where the daughter half-life $(64.1 \mathrm{hrs})$ is much less than that of the parent (28.6 years) as follows:

$$
\operatorname{INGTH}(\mathrm{t})=\left(1-\mathrm{e}^{\lambda \mathrm{Yt}}\right) \quad \text { Eq. } \mathrm{A}
$$

where $\lambda_{\mathrm{Y}}=$ radiological decay constant for ${ }^{90} \mathrm{Y}$

and $\mathrm{t}=$ time elapsed since the last complete separation of ${ }^{90} \mathrm{Y}$ from ${ }^{90} \mathrm{Sr}$

However, the ingrowth term is calculated for each sample in column W of the subcontractor laboratory's spreadsheet as follows:

$$
\text { INGTH }=\mathrm{D}-\mathrm{e}^{-\lambda \mathrm{Y} *\left[\text { Count Time }-\frac{\Delta \mathrm{t}-\text { Sep. Time }]}{2}\right.}
$$


where $\mathrm{D}=$ decay correction for ${ }^{90} \mathrm{Sr}$ from sample collection to sample analysis

Count Time $=$ time that the assay of ${ }^{90} \mathrm{Sr}$ using the GPC was completed

$\mathrm{t}=$ amount of time that the sample was assayed

Sep. Time $=$ time that separation of ${ }^{90} \mathrm{Sr}$ from ${ }^{90} \mathrm{Y}$ occurred during sample preparation .

The inclusion of the decay correction for ${ }^{90} \mathrm{Sr}$ (i.e., "D") in Subcontractor Laboratory Eq. 3 is incorrect. What is implied by the inclusion of " $\mathrm{D}$ " is that the time elapsed since sample collection (rather than the time elapsed since chemical separation as part of the analytical process) has some effect on the secular equilibrium of ${ }^{90} \mathrm{Y}$ with ${ }^{90} \mathrm{Sr}$ in the sample prepared for assay. Since any equilibrium would have been upset by the separation process, this is certainly not true. The correct expression for "INGTH" should always result in a number between 0 and 1 . The correction for sample decay since collection should have been performed at a later step in the calculations.

Having looked further at the February 17, 1998 fax, it was clear that the subcontractor laboratory then attempted to establish the relationship between the radiation count rate (in counts per minute, or "CPM") measured by the GPC and the amount of ${ }^{90} \mathrm{Sr}$ and ${ }^{90} \mathrm{Y}$ present using the above equations as follows:

$\mathrm{CPM}=(\mathrm{Sr}-90 \mathrm{DPM} * \mathrm{Sr}-90 \mathrm{EFF})+(\mathrm{Y}-90 \mathrm{DPM} * \mathrm{Y}-90 \mathrm{EFF} * \mathrm{INGTH}) \quad$ Subcontractor Laboratory Eq. 4

where $\mathrm{CPM}=$ radiation counts per minute attributable to ${ }^{90} \mathrm{Sr}$ and ${ }^{90} \mathrm{Y}$

$\mathrm{Sr}-90 \mathrm{EFF}=\mathrm{GPC}$ counting efficiency for ${ }^{90} \mathrm{Sr}$ beta particles

$\mathrm{Y}-90 \mathrm{EFF}=\mathrm{GPC}$ counting efficiency for ${ }^{90} \mathrm{Y}$ beta particles

Subcontractor Laboratory Eq. 4 is not correct. The error in this equation is in the second term, where the contribution of ${ }^{90} \mathrm{Y}$ activity to the total count rate is defined. This term incorrectly contains two corrections for ${ }^{90} Y$ ingrowth. The first correction appears explicitly as the variable "INGTH." The second correction appears implicitly in the variable "Y-90 DPM," which can be redefined by reorganizing Subcontractor Laboratory Eq. 2:

$$
\text { Y-90 DPM }=\text { Sr-90 DPM } * \text { INGTH. }
$$

Eq. B

There is no valid reason to account for the ingrowth of ${ }^{90} \mathrm{Y}$ in the sample more than once. Rather, the subcontractor laboratory should have defined the radiation counting rate response of the GPC as

$$
\mathrm{CPM}=(\mathrm{Sr}-90 \mathrm{DPM} * \mathrm{Sr}-90 \mathrm{EFF})+(\mathrm{Y}-90 \mathrm{DPM} * \mathrm{Y}-90 \mathrm{EFF}) \quad \text { Eq. C }
$$

By solving Eq. 4 for Sr-90 DPM, the subcontractor laboratory obtained the equation

$$
\text { Sr-90 DPM }=\frac{\mathrm{CPM}}{\left[\mathrm{Sr}-90 \mathrm{EFF}+\left(\mathrm{Y}-90 \mathrm{EFF} * \mathrm{INGTH}^{2}\right)\right]}
$$

However, the correct solution for Sr-90 DPM derived from Eq. C is

$$
\text { Sr-90 DPM }=\frac{\text { CPM }}{[\mathrm{Sr}-90 \mathrm{EFF}+(\mathrm{Y}-90 \mathrm{EFF} * \mathrm{INGTH})]}
$$


The subcontractor laboratory's actual implementation of Eq. 5 in the "Sr-90 in Soil Calculation Spreadsheet" was not straightforward. That is, there was no cell in their spreadsheet in which only Eq. 5 appeared. Rather, column $\mathrm{H}$ of the spreadsheet contained a formula similar to Eq. 5, except that (1) the ingrowth variable (INGTH) was not squared (so that it actually looked more like Eq. D) and (2) the Eq. 4-like term in these cells was multiplied by the ${ }^{90} \mathrm{Sr}$ GPC counting efficiency for zero sample mass to return "Net Sample CPM." The result was as follows:

$$
\text { Net Sr-90 CPM }=\frac{\mathrm{CPM}}{(\mathrm{Sr}-90 \mathrm{EFF}+\mathrm{Y}-90 \mathrm{EFF} * \mathrm{INGTH})} *(\mathrm{Sr}-90 \mathrm{EFF})_{\text {mass }=0} \quad \begin{gathered}
\text { Subcontractor } \\
\text { Laboratory Eq. } 6
\end{gathered}
$$

where CPM = raw counts per minute minus (1) GPC background, (2) a pre-determined bias of $0.01 \mathrm{CPM}$, and (3) a correction for alpha channel crosstalk into the beta channel.

The error in the derivation of Subcontractor Laboratory Eq. 5 was partially corrected by the actual implementation in the spreadsheet of Eq. D multiplied by the zero mass ${ }^{90} \mathrm{Sr}$ counting efficiency (as shown above in Subcontractor Laboratory Eq. 6). However, the application of the zero mass ${ }^{90} \mathrm{Sr}$ counting efficiency to calculate "Net Sr-90 CPM" was incorrect. The actual counting efficiency associated with the mass of the sample precipitated on the filter for counting should have been used, as follows, if the correct "Net Sr-90 CPM" were to be obtained:

$$
\text { Net Sr-90 CPM }=\frac{\mathrm{CPM}}{[\mathrm{Sr}-90 \mathrm{EFF}+(\mathrm{Y}-90 \mathrm{EFF} * \mathrm{INGTH})]} * \mathrm{Sr}-90 \mathrm{EFF}
$$

The calculation of the quantity of ${ }^{90} \mathrm{Sr}$ in the sample in the final units (e.g., pCi/gram [PCG]) was performed in column P of the subcontractor laboratory's "Sr-90 in Soil Calculation Spreadsheet." In these cells, a formula appeared as follows:

$$
\mathrm{Sr}-90 \mathrm{PCG}=\frac{\mathrm{Net} \mathrm{Sr}-90 \mathrm{CPM}}{2.22 * \mathrm{Sr}-90 \mathrm{EFF} * \mathrm{Y} * \mathrm{M} *(1+\mathrm{INGTH}) * \mathrm{D}}
$$

Subcontractor Laboratory Eq. 7

where $\mathrm{Sr}-90 \mathrm{PCG}=$ activity concentration of ${ }^{90} \mathrm{Sr}$ in the sample in units of $\mathrm{pCi} / \mathrm{g}$

2.22 = conversion from DPM to $\mathrm{pCi}$

$\mathrm{Y}=$ the recovery of ${ }^{90} \mathrm{Sr}$ through the radiochemical separation procedure

$\mathrm{M}=$ the total mass of sample processed

With regard to Subcontractor Laboratory Eq. 7, if the "Net Sr-90 CPM" had been correctly derived in column $\mathrm{H}$, then the use of the additional correction term for ingrowth (i.e., "1+INGTH") was not correct. The remaining variables for unit conversion, chemical recovery, mass of sample, and decay correction were used correctly. Using Eq. E as the basis, the correct equation for ${ }^{90} \mathrm{Sr}$ in the final units is

$$
\mathrm{Sr}-90 \mathrm{PCG}=\frac{\mathrm{Net} \mathrm{Sr}-90 \mathrm{CPM}}{2.22 * \mathrm{Sr}-90 \mathrm{EFF} * \mathrm{Y} * \mathrm{M} * \mathrm{D}}
$$




\subsection{Derivation of Uncertainty Term}

Using Equations $\mathrm{D}$ and $\mathrm{F}$ as the basis, the correct expression for the uncertainty term is (in units of $\mathrm{pCi} / \mathrm{g}$ )

$$
\text { Sr-90 unc }=\frac{1.96 * \sqrt{\frac{\mathrm{CPM}_{\text {raw }}}{\Delta \mathrm{t}_{\mathrm{raw}}}+\frac{\mathrm{CPM}_{\mathrm{bkg}}}{\Delta \mathrm{t}_{\mathrm{bkg}}}}}{[\mathrm{Sr}-90 \mathrm{EFF}+(\mathrm{Y}-90 \mathrm{EFF} * \mathrm{INGTH})] * \mathrm{M} * \mathrm{D} * \mathrm{Y} * 2.22} \quad \text { Eq. G }
$$

However, the equation in use by the subcontractor laboratory is as follows:

$$
\text { Sr-90 unc }=\frac{1.96 * \sqrt{\frac{\mathrm{CPM}_{\mathrm{raw}}}{\Delta \mathrm{t}_{\mathrm{raw}}}+\frac{\mathrm{CPM}_{\mathrm{bkg}}}{\Delta \mathrm{t}_{\mathrm{bkg}}}}}{\mathrm{M} * 2.22 * \mathrm{Y} * \mathrm{Sr}-90 \mathrm{EFF} *(1=\mathrm{INGTH}) * \mathrm{D}} \quad \begin{array}{r}
\begin{array}{r}
\text { Subcontractor } \\
\text { Laboratory Eq. } 8
\end{array}
\end{array}
$$

The above equation is very nearly like the equation that should have been used, except that it fails to accurately account for the fact that the ingrowing ${ }^{90} \mathrm{Y}$ radioactivity is counted with a somewhat higher efficiency.

\subsection{Derivation of the Minimum Detectable Activity (or Concentration)}

The derivation of the minimum detectable concentration (MDC) is similar to that for the uncertainty:

$$
\mathrm{MDC}=\frac{2.71+4.66 * \sqrt{\mathrm{CPM}_{\mathrm{bkg}} * \Delta \mathrm{t}_{\mathrm{bkg}}}}{\Delta \mathrm{t}_{\mathrm{raw}} *[\mathrm{Sr}-90 \mathrm{EFF}+(\mathrm{Y}-90 \mathrm{EFF} * \mathrm{INGTH})] * \mathrm{M} * \mathrm{D} * \mathrm{Y} * 2.22}
$$

Eq. $\mathrm{H}$

This is very similar to the equation used by the subcontractor laboratory:

$$
\mathrm{MDC}=\frac{2.71+4.66 * \quad \mathrm{CPM}_{\mathrm{bkg}} * \Delta \mathrm{t}_{\mathrm{bkg}}}{\Delta \mathrm{t}_{\text {raw }} * \mathrm{Sr}-90 \mathrm{EFF}+(1+\mathrm{INGTH}) * \mathrm{M} * \mathrm{D} * \mathrm{Y} * 2.22} \quad \begin{array}{r}
\text { Subcontractor } \\
\text { Laboratory Eq. } 9
\end{array}
$$

However, as with the uncertainty term discrepancy, the MDC derived by the subcontractor laboratory fails to accurately account for the fact that the ingrowing ${ }^{90} \mathrm{Y}$ radioactivity is counted with a somewhat higher efficiency. 


\section{0 COMMUNICATION BETWEENTHE SUBCONTRACTOR LABORATORY ANDWWNS REGARDING CORRECTIVE ACTIONS}

The subcontractor laboratory's initial responses to WVNS's inquiries regarding the ${ }^{90} \mathrm{Sr}$ data discrepancies were solicited and coordinated by the WVDP Data Validation Group, which is also staffed by D\&M personnel, primarily through the use of Data Provider Communication Forms (DPCFs). The Data Validation Group generally acts as the primary point-of-contact between WVNS data end-users and data providers such as the subcontractor laboratory. The DPCFs serve to document the end-user's questions and the provider's responses. The contract with the subcontractor laboratory requests that they respond to these questions within 10 working days. It is common in cases such as this is to request Level II documentation, which consists of various quality control performance results, sampling and preservation information, holding times, units, WVDP detection limits, laboratory sample identification information, and supporting data such as calibration information, instrument responses, tracer recoveries, and raw data.

\subsection{Communications with Subcontractor Laboratory Leading up to Quality Assurance (QA) Surveillance}

The questions raised by the Environmental Affairs Support scientists in late January 1998 were not the only evidence that a potential problem had occurred during analysis of WVDP samples. At the same time, WVDP Data Validation personnel received written notice from the subcontractor laboratory in several data packages that they had deviated from their sample preparation procedure for ${ }^{90} \mathrm{Sr}$ in biological samples in order to overcome some analytical interferences. This information was forwarded to Environmental Affairs Support by Data Validation. These coincident events led to the February 2, 1998 request by Environmental Affairs Support for detailed documentation of these analyses.

The subcontractor laboratory faxed Level II data to the Data Validation Group on February 5, 1998. Unable to reproduce the calculations from the raw data that was provided with the Level II data, Environmental Affairs Support requested a detailed explanation of the formulas and calculations embedded in the spreadsheet printout during a February 11, 1998 conference call between WVNS Procurement, the Environmental Lab, Environmental Affairs, Environmental Affairs Support, and the subcontractor laboratory. This information was faxed by the subcontractor laboratory to the Data Validation Group on February 12, 1998. Two scientists from the Environmental Lab and Environmental Affairs Support reviewed the additional information but were still unable to fully reproduce the calculations. A complete and annotated calculation was requested from the subcontractor laboratory on February 16, 1998 and, as a result, some additional information was received from the subcontractor laboratory on February 17, 1998. The errors were detected by Environmental Affairs Support upon review of this information. After the errors were identified and WVNS completed a technical position paper on the subject (the results of which are discussed in Section 3.0), conversations with the subcontractor laboratory began focusing on the implementation of corrective actions. On February 16, 1998, Environmental Affairs Support enlisted the assistance of the Data Validation Group to begin querying the environmental database for a list of potentially affected samples.

On February 18, 1998, WVNS Procurement, Environmental Affairs, Analytical \& Process Chemistry, Environmental Affairs Support, and Data Validation joined in a conference call with the subcontractor laboratory. At that time, the subcontractor laboratory acknowledged the error and agreed to begin the process of correcting the spreadsheet and reissuing corrected data to WVNS. The first priority was to generate a list of samples collected in 1997 that were affected by the errors so that year-end reports could be completed. This list was generated by Environmental Affairs Support and provided to WVNS Procurement on February 19, 1998. Procurement faxed the list to the subcontractor laboratory on February 19, 1998 to help the subcontractor laboratory begin 
establishing a list of affected sample results. However, at that time no information was yet available on the original software validation and verification of the spreadsheet that the subcontractor laboratory had used. As a result, the historical extent of the errors prior to 1997 was still not known.

On February 26, 1998, WVNS Quality Assurance issued a Quality Issues Action Request (QA0496-01) to the subcontractor laboratory requesting that they provide a description of the cause, proposed corrective action, and completion date for the identified errors by March 13, 1998. During this time period, the WVNS cognizant engineer for the subcontractor laboratory's contract, working as an agent for WVNS QA, visited the subcontractor laboratory with the intent of reviewing their software verification and validation procedures. An additional request for information was issued to the subcontractor laboratory on March 9, 1998 in which Procurement requested both electronic files and verification and validation $(\mathrm{V} \& \mathrm{~V})$ documentation for the original and revised spreadsheets. The subcontractor laboratory responded to this request on March 11, 1998.

The evaluation of the subcontractor laboratory's response was completed by Environmental Affairs Support on March 20, 1998. Two errors remained in the corrected spreadsheet provided by the subcontractor laboratory. One of these errors was an original error that remained uncorrected and that was described in the technical position paper provided by Environmental Affairs Support to Environmental Affairs on March 20, 1998. The other error was a new error introduced during revision of the spreadsheet. WVNS Procurement requested these additional corrections in a March 24, 1998 letter to the subcontractor laboratory. Documentation of these corrections was received by Procurement on March 26, 1998 and approval of all corrections and changes to the spreadsheet was provided by Environmental Affairs after another review by Environmental Affairs Support on March 27, 1998. As of April 2, 1998, the subcontractor laboratory had corrected these errors and submitted corrected results for ${ }^{90} \mathrm{Sr}$ concentrations in all WVDP samples for the 1997 calendar year. The subcontractor laboratory transmitted corrected results for 1995 and 1996 on April 22, 1998.

\subsection{Communication During WVNS QA Surveillance of Subcontractor Laboratory}

WVNS Quality Assurance assembled a surveillance team comprised of two of its own quality engineers, one representative from the Environmental Lab, and another representative from Environmental Affairs Support. The team conducted their surveillance of the subcontractor laboratory from March 31, 1998 to April 2, 1998.

During the surveillance at the subcontractor laboratory, the surveillance team spoke with many individuals responsible for different steps of the procedure for ${ }^{90} \mathrm{Sr}$ analysis in solids. On the morning of March 31, 1998, a brief tour of the subcontractor laboratory facilities was conducted by the laboratory's project manager.

\subsubsection{Spreadsheet Errors}

After the tour, the surveillance team spoke with a subcontractor laboratory team leader about the errors in the subcontractor laboratory's ${ }^{90} \mathrm{Sr}$ spreadsheet and their efforts to recalculate the WVDP ${ }^{90} \mathrm{Sr}$ data reported since 1995. He mentioned that some considerable effort would be required to open past spreadsheets and recalculate the data for the 1995-96 time period but that they would continue working on this. The team leader appreciated the WVDP's review of the spreadsheet and mentioned that the original basis for the spreadsheet was a request from another DOE contractor to calculate ${ }^{90} \mathrm{Sr}$ in a specific manner. The team leader also stated that upon realizing that the contractor's suggested calculations were not correctly compensating for the ingrowth of ${ }^{90} \mathrm{Y}$, the subcontractor laboratory revised the spreadsheets used for their other customers. (The other DOE contractor, however, preferred the continued use of the original equations for the sake of maintaining consistency with their historical data.) 
Note: During the discussion, the subcontractor laboratory confirmed that their corrected ${ }^{90} \mathrm{Sr}$ spreadsheet is used for all their customers, with the exception of the other DOE contractor, and that the error in the original spreadsheet would have affected any data reported from April 1995 through April 1998.

The team leader stated that the revised equations had never been reviewed by any of their customers until the WVDP inquired in February 1998. The surveillance team showed the team leader a copy of the ${ }^{90} \mathrm{Sr}$ spreadsheet verification documentation that was faxed to the WVDP in February 1998. He stated that what we received was actually not the spreadsheet verification documentation but rather the documentation for the new database that they are developing that is not yet on line. The team leader pointed out that the actual spreadsheet verification documentation, dated April 1995, was just recently found. The surveillance team then requested and received a copy of the actual "S90 Sr only" spreadsheet verification documentation.

\subsubsection{Sample Preparation}

A subcontractor laboratory group leader for sample preparation then took WVDP on a tour of the sample preparation areas. Sample preparation includes drying, pulverizing, homogenizing, and ashing samples to prepare them for analyses in the laboratory. No deficiencies were observed in the sample preparation procedures, although the surveillance team recommended that the potential for cross contamination should be monitored through the regular introduction of a blank at the beginning of the ashing procedure.

\subsubsection{Sample Analysis}

The surveillance team then spoke with a subcontractor laboratory analyst who routinely performs the ${ }^{90} \mathrm{Sr}$ procedure. The analyst could only discuss the modified ${ }^{90} \mathrm{Sr}$ analytical procedure because no samples were being analyzed at that time. The analyst told WVDP that he had recognized for some time the need for additional sample preparation steps to improve the analytical recovery of strontium, but that the "production" mode of the laboratory precluded an investigation and procedure change until this year. The analyst mentioned that, in some cases, the precipitate did not appear to be strontium carbonate but rather some other compound. The surveillance team suggested that the chemical analysis of precipitates may help identify the interfering material.

The subcontractor laboratory analyst also mentioned that some "miscommunication" had resulted in the subcontractor laboratory not performing the full strontium-89/90 procedure whenever a value above the method detection limit (MDL) was observed on the initial radiostrontium $\left({ }^{89} \mathrm{Sr}+{ }^{90} \mathrm{Sr}\right)$ assay. He stated that beginning February 1998 the WVDP should expect to see the full analysis performed on all the WVDP samples for which the initial count contains radioactivity above the MDL. As a result of this conversation, the surveillance team requested and received a copy of the spreadsheet (with formulas shown) used to calculate strontium-89/90.

The surveillance team asked the analyst about the use of 3.0 molar (M) nitric acid as a rinse solution for the Eichrom Sr-Spec columns, instead of 8.0 M, which is used as the loading solution. The analyst explained that the 3.0 M serves as an intermediate transition from the $8.0 \mathrm{M}$ loading solution to the $0.05 \mathrm{M}$ eluant solution. The surveillance team pointed out that the optimum separation of strontium from other interfering elements (such as potassium) on the Eichrom Sr-Spec resin occurs in 8.0 M nitric acid. The analyst referred us to senior technical specialists for further questions about method development. No procedural deficiencies were noted as a result of our conversation with the analyst. 
In the afternoon of March 31, 1998, the surveillance team spent some time talking with both senior technical specialists. There is no method development documentation available for the modified procedure, but a senior technical specialist assured us that the method now used is equivalent to U.S. Environmental Protection Agency (EPA) and U.S. Department of Energy (DOE) methods. We showed both senior technical specialists the results of the original ${ }^{90} \mathrm{Sr}$ analysis results for annual apple samples that were sent to the subcontractor laboratory under WVDP sample lot number 184 (i.e., "release" 184) that were analyzed using the ${ }^{90}$ Sr-only procedure. We also showed them the hold apple sample reanalysis results reported in release 204 that were analyzed using the strontium-89/90 procedure. The results reported in release 184 are slightly higher than expected but a good result was obtained for a blind cross check sample (Environmental Measurements Laboratory [EML] Quality Assessment Program [QAP] 45). The results reported for the hold samples in release 204 were more consistent with expected results, but the subcontractor laboratory performed poorly on the vegetation cross check sample (EML QAP 47). Neither senior technical specialist could offer an immediate explanation, but one promised to look into the discrepancy.

On Wednesday, April 1, 1998, we spoke with the manager of the subcontractor laboratory to discuss the discrepancy in the two reported apple sample releases and the recent poor cross check performance on EML QAP 47. Upon conferring with a subcontractor laboratory Quality Assurance representative, the manager confirmed that the subcontractor laboratory did not report a value to EML for ${ }^{90} \mathrm{Sr}$ in either the soil or vegetation matrix for QAP 47. The manager explained that the nearly zero recovery of strontium in their analysis of the QAP 47 samples precluded their getting an accurate number for reporting. He told us that he would get back to us with an explanation once he spoke with his staff.

The remainder of our conversation with the manager focused on the decision to use either the ${ }^{90} \mathrm{Sr}$-only procedure (and its associated spreadsheet) or the full strontium-89/90 procedure (and its associated spreadsheet) in the analysis of WVDP samples. The manager offered to repeat the analysis of QAP samples with an extra radiation counting step. With this extra step, the procedure would result in three separate counts: (1) the initial count of the total radiostrontium $\left({ }^{89} \mathrm{Sr}+{ }^{90} \mathrm{Sr}\right.$ ) immediately after precipitation from the sample (which is part of the EPA HASL-300 method for strontium-89/90); (2) a second count of the same precipitate after 5 to 7 days to confirm the ingrowth of ${ }^{90} \mathrm{Y}$ (a step that is not routinely performed, but that will help confirm if all or just some of the initial total strontium is ${ }^{90} \mathrm{Sr}$ ); and (3) a count of the ${ }^{90} \mathrm{Y}$ precipitate obtained from dissolution of the first precipitate (which is part of the EPA method for determining how much of the total radiostrontium is ${ }^{90} \mathrm{Sr}$ ).

\subsubsection{Eichrom Resin Damage}

Near the end of Wednesday, April 1, 1998, a senior technical specialist reported a problem to WVDP that the subcontractor laboratory had identified in the preparation of Eichrom Sr-Spec resin material for use in columns. The senior technical specialist explained that $\mathrm{Sr}-\mathrm{Spec}$ is purchased in bottles from Eichrom and then prepared for use in columns at the subcontractor laboratory. This preparation involves placing the resin in deionized water in a flask and stirring the resin/water slurry with a magnetic stirrer bar to help remove unwanted inert or foreign material, which settles out. However, in at least one circumstance, a batch of resin was stirred much longer than the prescribed 1 to 2 hours. As a result, the resin was damaged. This fact was confirmed through consultation with Eichrom and by microscopic examination of the resin. The senior technical specialist felt that this explained the poor recovery of strontium in their effort to report both the EML QAP 47 results and the apple results associated with release 204. By the time of the close-out meeting on April 2, 1998, the subcontractor laboratory provided assurance that they had corrected this problem. 


\subsubsection{Software Verification and Validation Procedures}

WVNS QA reviewed the subcontractor laboratory's software verification and validation procedures during the surveillance. The software control program was deemed sufficient. Validation is to ensure that the completed software meets specified requirements and is suitable for its intended use, is sufficiently documented. However, WVNS QA suggested that validation should be performed by a subject matter expert. Verification, which refers to the process of ensuring that all requirements of a software life cycle phase have been met at the end of that phase, is not being performed. Rather, the subcontractor laboratory combines verification and validation into one step with the assumption that if values correspond, then the calculation must be correct. A recommendation was made that each equation that the subcontractor laboratory plans to use be subject to verification by a subject matter expert.

\subsubsection{Summary of Subcontractor Laboratory Actions Agreed to During Surveillance}

1. The subcontractor laboratory agreed to reanalyze the vegetation EML QAP samples submitted with WVDP samples to demonstrate that their procedure will produce accurate results now that the cause of the original failure (i.e., the damaged Eichrom Sr-Spec resin) has been identified. The results of these analyses were acceptable.

2. The subcontractor laboratory agreed that it would be prudent to process blanks through the entire procedure for ${ }^{90} \mathrm{Sr}$, including the initial sample ashing part of the procedure, in order to monitor for potential cross-contamination or other interferences. WVNS has received these blank results for each sample batch submitted to the subcontractor laboratory since April 1998. 


\section{0 DESCRIPTION OF EFFECTS ONWWDP OPERATIONS}

The errors in the subcontractor laboratory's ${ }^{90} \mathrm{Sr}$ spreadsheet were detected during the busiest time of the year for the Environmental Affairs Support organization. Annual data reports to EPA and DOE were being assembled. Several chapters of the annual Site Environmental Report had already been drafted containing analyses and conclusions based, at least in part, on more than $200{ }^{90} \mathrm{Sr}$ results that had been reported for 1997 environmental samples. In fact, the discovery of an error in the reporting of ${ }^{90} \mathrm{Sr}$ concentrations was exacerbated by its presence and relative mobility in on-site groundwater, its detectable presence in several air and water effluents, and its general relative abundance as a fission product at the site (it represents nearly half of the radioactivity being vitrified in the WVDP Vitrification Facility, for example).

\subsection{Extent of Affected Data}

When the actual software verification and validations forms for the spreadsheet were provided to the WVNS surveillance team, it was determined that the spreadsheet had been in use since at least April 1995. For this reason, WVNS requested that the subcontractor laboratory recalculate and transmit all ${ }^{90} \mathrm{Sr}$ results for samples collected from January 1995 through the end of 1997. This amounted to results for nearly 600 samples. The types of samples included quality assurance cross-check samples, groundwater, air filters, soil, sediment, milk, beef, deer, apples, beans, corn, hay, and fish.

\subsection{Effort Required to Restore WVDP Environmental Database}

The recovery of useful and valid ${ }^{90} \mathrm{Sr}$ data from the subcontractor laboratory after discovering the errors in their spreadsheet required well over 500 man-hours and the participation of many WVNS and contractor organizations. Effective and consistent communication between the on-site groups and the subcontractor laboratory was difficult to maintain at times, but by establishing primary points-of-contact and using e-mail to communicate the status of on-going efforts between organizations, the task remained manageable and original contract deliverables stayed on schedule. 


\section{0 LESSONS LEARNED ANDSUGGESTIONS FOR FUTURE IMPROVEMENTS}

The discovery of the error in the subcontractor laboratory's spreadsheet demonstrated the benefit of maintaining vigorous data validation and data assessment procedures for evaluating environmental monitoring and surveillance data.

Addressing the consequences of this error has stressed the importance of effective data management practices, e.g., methods for evaluating the extent of the error (e.g., data reports, trend evaluations, dose assessments), and protocols for correcting the affected data and reports.

The discovery of this error demonstrated the importance of an effective program for both software verification and software validation. In the subcontractor laboratory's case, the spreadsheet had been verified (i.e., the correct results were obtained for each equation), but the spreadsheet had not been validated (i.e., the equations themselves were incorrect).

Finally, the following suggestions are put forth:

- Periodic Level II data inspection should be included in the validation process for critical environmental samples.

- Implementation of an effective software verification and validation program should be a major focus of preaward surveys for radiochemical laboratory services.

- Users of the subcontractor laboratory ${ }^{90} \mathrm{Sr}$ data that was provided from April 1995 through April 1998 should attempt to recalculate their ${ }^{90} \mathrm{Sr}$ results. 


\subsection{REFERENCES}

Scarpitta, S., Odin-McCabe, J., Gaschott, R., Meier, A., and Klug, E. November 12, 1997. "Comparative Results of Four Sr-90 Groundwater Analytical Methods," Analytical Services Laboratory of Brookhaven National Laboratory, Presented at 43rd Bioassay, Environmental and Radiochemistry Conference, Charleston, SC.

United States Environmental Protection Agency. August 1980. "Prescribed Procedures for Measurement of Radioactivity in Drinking Water, Method 905.0," EPA-600/4-80-032.

United States Department of Energy. November 1990. "Environmental Measurements Laboratory Procedures Manual, Section 4.5," HASL-300, 27th Edition, Volume 1. 
Strontium-90 Error Discovered in Subcontract Laboratory Spreadsheet 